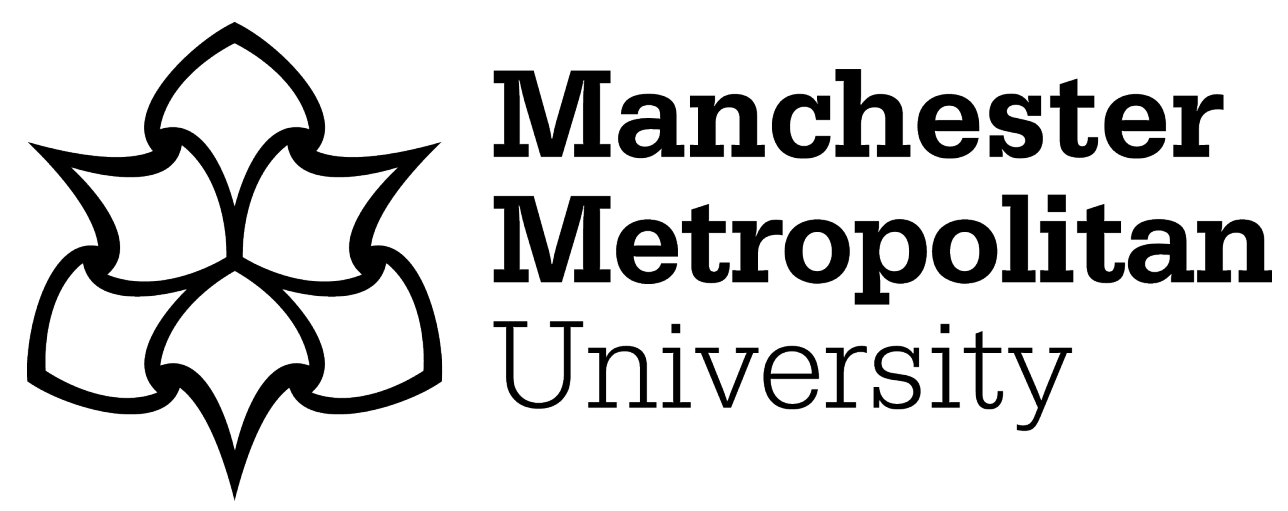

Holmes, Rachel, Jones, Liz and Osgood, Jayne (2018) Mundane Habits, Ordinary Affects, and Methodological Creations. In: Research Handbook on Childhoodnature: Assemblages of Childhood and Nature Research. Springer International Handbooks of Education (SIHE) . Springer. ISBN 3319672851

Downloaded from: https://e-space.mmu.ac.uk/621531/

Version: Accepted Version

Publisher: Springer

DOI: https://doi.org/10.1007/978-3-319-51949-4_20-1

Please cite the published version 


\title{
Mundane habits, ordinary affects and methodological creations
}

Rachel Holmes, Liz Jones and Jayne Osgood

\begin{abstract}
The aim of this chapter is to rethink 'thought' in qualitative inquiry. We attend to possibilities that open up when we turn our attention to habits, ordinary affects and methodological creations that are integral to the ways in which we think. The challenge of putting new materialism and post-humanism to work requires significant ontological and epistemological shifts. Nevertheless, it is only by shifting the ground on which specific knowledge claims are made that we can potentiate a different logic which in turn can alter both thinking and, importantly, early years practice. Thus this chapter will resolutely refute general ideas or models of what constitutes familiar objects in early childhood settings, for example 'the cardboard box', or 'the snowman' [sic]. Instead, such models, in situating them within a 'zone of indeterminacy' (Massumi, 1993, p. 99) are, as a consequence freed from habitual assumptions - assumptions that, in our view, delimit the possibilities of what is possible. The chapter works with objects and processes, deliberately avoiding foregrounding the child, to leave the uncertainty and ambiguity of which things are in play, alive in the text. Through experimental methods the chapter will draw on two early years projects: 2-curious (a programme of continued professional development for early years practitioners in Manchester, UK) and Knotknowing Diversity in Early Childhood (a research project reexamining 'multicultural education' in an early years setting in London, UK) as generative examples of the potential of the entanglements observed during ethnographic research that take matter and materiality as their starting place.
\end{abstract}

\section{Keywords: Habit, affect matter, process ontology}

\section{Introduction}

The aim of this chapter is to rethink 'thought' in qualitative inquiry. As we shall outline throughout this chapter there is a pressing need for us to rethink the habits that surround, circumscribe and limit what it means to think and what it means to know. As academic researchers much of our work is located within the terrain of childhood and early years education. As Peter Moss (2014) points out early childhood education has globally assumed importance amongst what he describes as the "movers and shakers of contemporary life" (2014, p. 3) or, in plain speak, policy makers. Like Moss we have fought and we will continue to fight for children to have access to early years education. But like all education, early years education can and does have the potential: "for governing children and adults alike, for reproducing the already known, for inculcating beliefs in necessity and 
essentialism, and for fostering the values and subjectivities required by a rapacious, technocratic and harmful economic regime" (Moss, 2014, p. 3).

Early years education is then a tricky terrain where certain global narratives including those associated with progress, development and economics work at (re)producing ideological configurations of the child, childhood and education, where children are perceived and understood as human capitol who will procure economic salvation and social stability. However, whilst this discourse is clearly dominant it can be challenged. But, as we shall go on to argue, it is a challenge that demands dislocating, displacing and dislodging habits including habits of thought. Whilst recognising the importance of contributing to debates that politicise relations between the child, culture and nature, we continue to wrestle with the term 'childhoodnature' (Malone, 2016; Taylor, 2013). Acknowledging the need to queer habits of thought that fall into easy associations and can leave neologisms impoverished, we deliberately refrain from making a direct reference to this term in this chapter.

In our efforts to challenge our habitual practices we have found it timely to remind ourselves of the etymology of 'research'. 'Research' stems from recerche and recercher - a mix of Old and Middle French (which are historical divisions of the French language that includes the period prior to $14^{\text {th }}$ and up to the early $17^{\text {th }}$ century) where each means "to seek out and to search closely". The addition of 're' is also interesting where it expresses or denotes an intensive force in relation to the seeking and the searching. In the subsequent sections of this chapter our efforts are directed at bringing these intensive forces to the fore because, in our view, it is these which can challenge habitual ways of thinking and habitual ways of claiming knowledge. In evolving this chapter our efforts are directed at bringing new materialism and posthumanism into play so as to undertake both an ontological and epistemological shift. This is because both "enforce the necessity to think again and to think harder about the status of human subjectivity, ethical relations, norms and values" (Braidotti, 2013, p. 186).

\section{Patterns of (habitual) thought}

Whilst we want to critique some of the mundane practices that attend our habitual ways of thinking we also recognize that critique by itself is an insufficient antidote. As Latour (2004) forewarns, critique on its own has 'run out of steam' whilst Braidotti (2006) argues that there has to be an 'intimate connection between critique and creation' (p. 6). Deleuze and Guattari (1994) map out how this connection between critique and creativity might be evolved: 
To criticize is only to establish that a concept vanishes when it is thrust into a new milieu, losing some of its components, or acquiring others that transform it. But those who criticize without creating, those who are content to defend the vanished concept without being able to give it the forces it needs to return to life, are the plague of philosophy (Deleuze and Guattari, 1994, p. 108).

We argue that it is by wrangling and plundering this 'connection' that we are enabled to imagine alternatives, ones that allow for an ethics of (re-)affirmation. Through experimental and uncertain methods the chapter will draw on two early years projects: 2-Curious (a programme of continued professional development for early years practitioners working with two-years-olds in Manchester, UK) and Mapping Children's Entanglements with Diversity through/within Celebrations, Festivals and Events (a research project re-examining 'multicultural education' in an early years setting in London, UK). Both are illustrative examples of a new materialist process ontology that allows for "an open, relational self-other entity framed by ... affectivity, embodiment, empathy and desire" (Braidotti, 2013 , p. 26). As a consequence, both examples look to rhizomatic dynamics of repetition and difference (Deleuze, 1994; Williams, 2013) rather than social constructivist binary oppositions. As Bennett suggests such binaries can result in a "partitioning of the sensible" (Bennett, 2010; Rancière, 2001) where, as an example, we divide the "the world into dull matter (it, things) and vibrant life (us, beings)" (Bennett, 2010, p. 8). It is within this habit that "power snaps into place", where "structures grow entrenched. Identities take place. Ways of knowing become habitual at the drop of a hat" (Stewart, 2007, p. 15). Our argument is that such habits of thinking and doing research are saturated in a human-centredness that is sustained by the tendency to cling to what Braidotti describes as the "reassuring familiarity of common sense" (2013, p. 1) where narratives of rationality, normality, progress and mastery are secured.

We would argue that there is an enormous price to pay for persistently seeing the human as unique. It requires that we continue to ignore what is habitually and "typically cast into the shadows" where we are, as a consequence, prevented from "detecting (seeing, hearing smelling, tasting, feeling) a fuller range of nonhuman powers circulating around and within human bodies" (Bennett, 2010, p. xi). If we continue to see matter as dead we will continue to cheat matter out of the fullness of its capacities. As Braidotti (2013) argues, we already live and inhabit social reality in ways that surpass tradition where technological innovations including advanced prosthetics, reproductive technologies, genetically modified food are all 
such familiar facets that distinctions between human and non-human become non-tenable. Yet, paradoxically, despite the complexities of a world, "where people... knowledge, values and ideas travel, cross national borders and encounter each other" (Olsson et al, 2015, p. 717), education - especially early years education - continues to favour reductionist thought (Holmes \& Jones, 2016; Moss, 2016; Cannella, Salazar Pérez \& Lee; 2015; Dahlberg, Moss \& Pence 1999/2013).

Following Law (2004) we ask: Can we "unmake our methodological habits"? Can we live without the desire for certainty? Can we "unmake our desire and expectation for security" (Law, 2004, p. 9)? If, as both Ravaisson (2008) and Deleuze (1994) argue, habits are what render the subject coherent to itself where they serve as ontological anchoring points to "the on-going flow of experience" (Lapworth, 2013, p. 5) can we and should we be implicated in intra-actions that might overwhelm such coherency? If, as Massumi suggests "habit is the body's defence against shocks of expression" (Massumi, 2002, p. 28), is it ethical to disturb such defences? In attempting to answer these questions we look to both Ravaisson (2008) and Deleuze (1994) who both similarly note that it is within the turmoil of overwhelming movements that there become possibilities for "cleaving open a conduit for action and response" (Lapworth, 2013, p. 5), thus positioning habits as sites for making change possible.

The following section of the chapter focuses on ways to tilt our mundane methodological and thinking habits. Resisting the habitual parsing of dull matter and vibrant life worlds, we try to re-think our thoughts as we get caught up with the movements and processes of ordinary affects.

\section{Conduits for action and response: ordinary affects}

Work emerging from the 'affective turn' (Clough, 2007; Massumi, 2002, 2015; Bennett, 2010; Deleuze and Guattari, 1987) relates to bodies, but as Guillaume and Hughes (2011) point out, the human body is not the focus of thinking here, as a concept, nor as a context. 'Bodies' are Spinozist configurations,

... not defined by form, rather it is the potential of motion and rest and the effects of the body's motion and rest in relation to other 'bodies'. In this case, a body is considered to be an 'infinite arrangement of particles', (Deleuze 1992)... which 
could be anything; an animal, an idea a collection of things or people. (p24)..." (Wood, 2009, p. 24).

So, for example, the power of bodies (the particles, odours, shape, surface textures and concept that constitute a cardboard box) to affect other bodies (the biological, physiological, sensorial, emotional and cognitive apparatus of the human) includes a "corresponding and inseparable" capacity simultaneously to be affected (Bennett, 2010, p. 21). This means the boundaries that might traditionally prescribe subject or object, life or matter, dull or vibrant are confused, even eradicated to produce a series of intra-active, fluid relations. Importantly, this notion of correspondence and inseparability is not about identity and fixity but about motion and rest and being in processes. As Deleuze and Guattari write,

We know nothing about a body until we know what it can do... what its affects are, how they can or cannot enter into composition with other affects, with the affects of another body, either to destroy that body or to be destroyed by it, either to exchange actions and passions with it or to join with it in composing a more powerful body (1987, p. 257).

Key writers in this field consider affect as some thing pre-individual, coming from 'outside' bodies (Massumi 2002; Thrift, 2008), yet passing over and through bodies, becoming constituted in feeling and eventually hitting "the cognitive apparatus" (Knudsen and Stage, 2015, p. 4). Along with many others (Blackman, 2012; Thrift, 2008; Brennan, 2004; Ahmed, 2004; Knudsen and Stage, 2015), we are interested in the potential of 'affect' to erode our anthropocentric habits, transforming the way we think about and approach empirical work, particularly the traditional colonial relationship between the vibrant human 'interpreter' and the dull or dead 'interpreted' material.

For Knudsen and Stage (2015), the relationship between affect and research lies in researchers being able to generate agendas and ask questions relating to affective processes; collect or produce embodied data; and make sense of the data in the production of academic knowledge. Our interest lies in re-thinking how affect pushes us towards a "zone of inventiveness" (Knudsen and Stage, 2015, p. 3) or methodological creation, by becoming attentive to 'data' in new ways, generating new types of empirical materials and, as Knudsen and Stage suggest, "collect[ing] material that has previously been perceived as banal or unsophisticated" (2015, 
p. 3), mundane or ordinary. We are interested in the affective powers of particular material relations (Svirsky, 2015, p. 50).

Mindful that when working creatively we need to develop better understandings of affective methodologies, there appears to be an urgent need to work through what bodies of movement, rest and affect might $d o$ to each other and to all participating entities. In what way might thinking is this way be useful methodologically? What are the implications ontologically and epistemologically? We need to grapple with generating affect both in terms of its generative potential but also in terms of its capacity to trouble us. Where the objective is to register affect in research, there is then an investment in entering an event/situation/ encounter with the goals of becoming-with; entanglement; presentpresence; attending to the microscopic; observation, documenting processes. Research methodologies such as performances and practice experiments intended to generate affect might include being: performative, orchestrated, choreographed; deliberately provocative; expansive.

Hickey-Moody (2016) claims that practice as research remakes/remaps/reconfigures how a given subject is constituted. This is because affective methodologies designed to generate affect change subjects. We argue, therefore, that research must be transversal, that is able to follow, or sense the multifarious connections and intensities that coalesce in events. It must also be oriented towards eventualities that cannot be foreseen and avoid privileging human agency. Yet degrees of caution are necessary given that there are clearly ethical implications surrounding the effects of the affects. That is, we have an ethical responsibility in terms of what we do and what that does.

\section{Methodological creations}

This next section of the chapter moves across two research projects to potentiate/illustrate our creative methodological movements. Firstly, we turn to 2-Curious (2013 -15), a Manchesterbased continued professional development (CPD) programme developed by researchers and academics from Manchester Metropolitan University in partnership with four early years settings, in Greater Manchester. Secondly, we turn to Mapping Children's Entanglements with Diversity through/within Celebrations, Festivals and Events (2016- ongoing), in a London-based early years setting with educators, and children aged 8 months to 5 years.

The 2-Curious CPD programme was prompted by the UK Government's initiative 'Two year old early education entitlement' (DfE, 2011, 2015) that allows eligible children to receive 
free early education and care. As a policy it seeks to "improve outcomes for identified two year olds who would benefit from access to high quality early years and childcare provision" (DfE, 2015). In terms of 'eligibility', this is based on economic factors (for example, receiving benefits such as Income Support, or tax credits where there is an annual income of under $£ 16,190$ before tax) as well as factors associated with risk and vulnerability (for example, a child who is being looked after by a Local Authority or a child who is receiving a disability allowance). This policy initiative follows a global pattern of many other programmes that are targeted at disadvantaged young people where the idea of 'improving outcomes' infers that, first, these have been predetermined and second that professional knowledge production and application will be concerned with, and based on the certainty of the results (Biesta, 2007; Cannella, and Soto, 2010). Educational settings, including mainstream primary schools, that offer the two year old entitlement have, almost inevitably, become embroiled in what Dahlberg and Moss (2005) describe as, "seeking the best methods and procedures to delivering predetermined outcomes" (cited in Olsson, 2009: 81). It is this mundane 'inevitability' that our research sought to destabilize, interfere with and, at times, disrupt. Wallins graphically captures much of what we sought to interfere with:

Regulated like zoo animals, teachers and students trace a deep rut at the threshold of their cages, habitually drawn back upon a course of life set out in advance. That is to say the curriculum-as-plan constitutes a ready made territory that always already marks a threshold for what should be thought or produced pedagogically (Wallin, 2013, p. 198).

At its simplest, the 2-Curious research project is characterized by the Deleuzian concept, of 'always becoming' where intra-actions between bodies, affect, matter, materials, practices, politics, objects, discourses and theories simultaneously work with old habits whilst potentiating different habitual manifestations. The CPD sessions that were developed were understood as, "points of affective openness to the strangeness of life itself" (Mitchell, 2010, p. 89). The aim therefore was to plan, implement, observe and analyse six experimental sessions that would unsettle the habits, practices and assumptions of those working with 'disadvantaged' or 'funded' two-year-olds.

At this point, we plunge into the middle of one of the 2-Curious CPD sessions because, following Deleuze (1994) to push, sink and flounder in the middle potentiates degrees of strangeness. MacLure elaborates further when she writes, "The middle can be a depthless and 
directionless (non-)place where subjects and objects no longer behave themselves or take up the places allotted to them by the rules of theory, methodology, or institutional discourses" (MacLure, cited in Cannella, Pérez and Pasque, 2016, p. 107). It is the middle that we momentarily find ourselves working with(in) thought and ordinary affects, trying to tilt our own methodological habits.

In this particular CPD session, various agents including cardboard boxes of various sizes, together with practitioners, researchers, space and other physical and physiological bodies activated various intensities, unpredictable mobile fault lines and energetic currents.
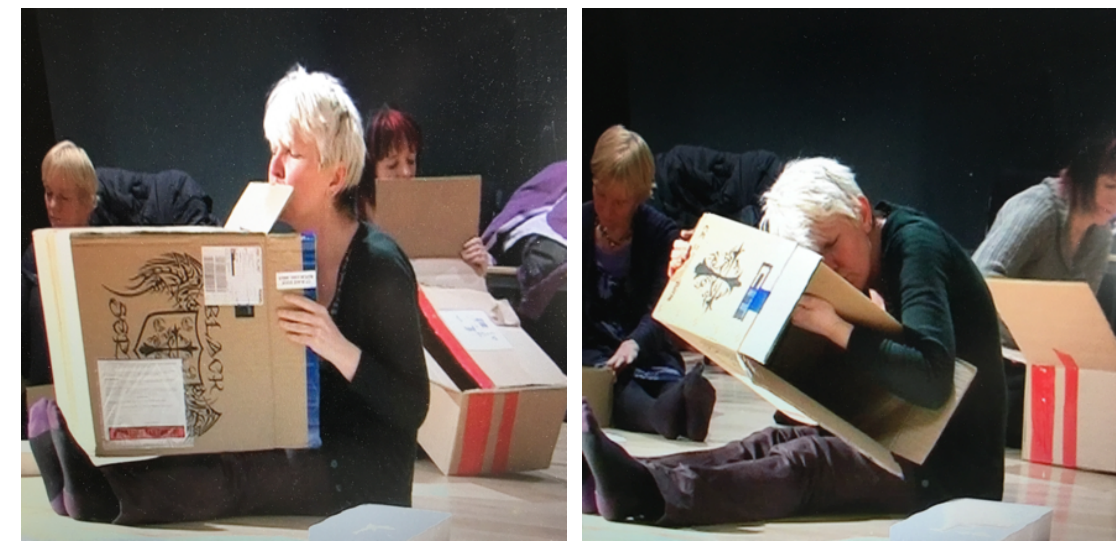

Video stills from 2-Curious CPD Project 2013

\section{"Close your eyes... can you feel}

the box with other parts of your body other than your hands?"

“Does your box have any taste?" (Session leader, 2014).

The particles, forces and odours of well-worn cardboard boxes re-negotiated the boundaries and sensations through intra-actions between bodily flesh and matter. Lines of flight travelled unpredictably provoking resonances that moved across and within bodies. Intimacy traversed between prosthetics where the diluted, dissolving boundary between box/body produced and procured sudden impulses. Strange encounters interrupted and fractured the familiarity of a hug. Movement was released, and given permission to unfold in unexpected ways. Ways that were neither dependent on or attached to predetermined outcomes. Bodies were allowed to speak in the subjunctive, "what if?" rather than tied to habit.

As an object the cardboard box is deeply familiar in early years settings. Children climb and hide in them. They are useful containers for practitioners to pack and store resources. Such an habitual relationship insists that the box being is constituted and characterised as dull or dead 
matter where the human body has vibrancy, life and agency. Within this well trodden furrow, the box is no more than "... "dumb matter" to be moulded or informed by human interpretation or inspiration (Massumi, 2002, p. 173)" (MacLure, 2013, p. 228). The CPD session sought to undermine such an impoverished encounter between human and non-human bodies. The session (and us as researchers) struggled to think about what might emerge from Bennett's "corresponding and inseparable" capacity of different bodies to be affected by, and simultaneously affect each other (2010). How could we think about unravelling the body's organisation, unmaking 'our thousands of component habits' (Deleuze, cited in Hroch, 2015, p. 61)? Mitchell posits such work as an affective event,

$\ldots$ it does not begin with the attributes of the 'object' in order to define it as if it were something static that can be described and understood.... The 'object' on its own is not sufficient; it is also necessary to include its affects ... (2010, p. 28).

Bissell suggests that our habits of thought are open to transformation both through 'subtle alteration and gradual, incremental change' (Bissell, 2012, n.p.) as well as "more sudden irruptions in the tissue of experience brought about by the shock of an encounter" (Lapworth, 2013 , p. 3). Provocations of shock and discomfort that were prompted by the unexpeceted imbibed the (extra)ordinary cardboard box with "surging capacities to affect and to be affected". Set within the assemblage something was released, where a continual motion of relations, scenes, contingencies and emergences unfold. Impulses were triggered. Sensations, expectations, daydreams, encounters, and habits were set in circulation. Non-hierarchical attachments formed where different bodily allegiances were constituted. "Something that feels like something" happened (Stewart, 2007, p. 4). For one actor this "something" was articulated as "acute discomfort", made more so when "my eyes were closed".

There are two significant points we want to make at this juncture. The first centres on Barad's "practices of diffraction, of reading diffractively for patterns of differences that make a difference" (reference needed). We want to suggest that in the cardboard box CPD session, where multiple entanglements occurred, various and varied irritations happen. These allow for careful readings "for differences that matter in their fine details", together with the recognition that, "intrinsic to this analysis is an ethics that is not predicated on externality but rather entanglement" which, as Barad argues are "respectful, detailed, ethical engagements". 
In brief, "diffractive readings bring inventive provocations; they are good to think with" (cited in Dolphijn \& van der Tuin, 2012, p. 49).

"Acute discomfort" as a practice of diffraction calls into question what is ordinarily and customarily expected from continuing professional practice where typically the focus is on consolidating and extending individuals' strengths. As Stewart points out,

The ordinary can turn on you. Lodged in habits ... it can flip into something else altogether. One thing leads to another. An expectation is dashed or fulfilled. An ordinary floating state of things goes sour or takes off into something amazing and good. Either way, things turn out to be not what you thought they were... The ordinary is a thing that has to be imagined and inhabited (2007, p. 105).

In these encounters, matters of fact, including those relating to boxes and humans, intra-acted with matters of concern and matters of care which emanated into resonances and dissonances. It is these that "make up diffraction patterns that make the entanglements visible" (Barad, 2003). Kirby follows a similar trajectory when she writes, "matter appears as something that is not only spoken about or spoken with, but rather as itself simply speaking. Nature and culture, word and flesh are "all emergent within a force field of differentiations that has no exteriority in any final sense" (Kirby 1997, p. 126-7, original emphasis). Perhaps, it is "beneath the generalities of habit in moral life we rediscover singular processes of learning" (Deleuze, 1994, p. 28).

The second point relates to the question of seeing, where having one's eyes closed exacerbated feelings of discomfort. Deleuze and Guattari (1987) urge us to use our eyes differently.

"I felt uncomfortable closing my eyes... it made me feel vulnerable" (participant, 2Curious, 2014)

Deleuze and Guattari intimate that the habits of the eyes, as organising forces render things already known, legible, over-coded. A body's organisational habits dictate that seeing is a function of the eyes, breathing is a function of the lungs, and thinking is a function of the brain, yet "My eyes are useless, for they render back only the image of the known. My whole body must become a constant beam of light..." (Deleuze \& Guattari, 1987, p. 190). In the 
data above, the methodological idea of 'closing my eyes' is interesting in relation to opening up the body to different encounters where without the principle of organisation, bodies are afforded new kinds of existence. What work does this action do to habits of the body, of sensations? What might happen if we were to close our eyes and 'see' otherwise?

"Is it really so sad and dangerous to be fed up with seeing with your eyes, breathing with your lungs, swallowing with your mouth, talking with your tongue, thinking with your brain, having an anus, a larynx, head and legs? Why not walk on your head, sing with your sinuses, see through your skin, breathe with your belly... Where psychoanalysis says, 'Stop, find yourself again,' we should say instead, 'Let's go further still, we haven't found our BwO yet, we haven’t sufficiently dismantled our self." (Deleuze and Guattari, 1987, p. 51).

In the event of 'closing my eyes' the participant was returned to the "thingness" of the box, evoking a sensation of vulnerability and performing a process of dis-mantling the habits of looking, seeing, coding and interpreting. Dismantling some of the habitual functions of the face means no longer looking with her eyes, “...but to swim through them, to close your eyes, to close your own eyes, and make your body a beam of light moving at ever-increasing speed" (Deleuze \& Guattari, 1987, p. 187). The box and that which is ordinarily and habitually attached to a box took on another form where its textures, edges, sound, tastes were entangled with parts other than the eyes. Both as a concept and as an object the box began to shift, where it was encountered as "sensation". As with Picasso's figurative paintings that overturn the rules of appearance, "so that form could pass directly from the eye to the stomach without going through the brain" (Francis Bacon cited in Deleuze, 2013, p. 38) so too did the box. We suggest that in moments when eyes were closed, encounters with the form of the box passed directly from the hands, or mouth, or cheek to the stomach, as sensations, which as Massumi notes, “...call habit to eventful attention. They impinge with force. They impact. They arrive, and insist ..." (1998, p. 155). We would argue that the sensations of becoming 'uncomfortable' and 'vulnerable' are produced as part of a process of mutual constitution of body (subject) and cardboard box (object), two entities that, after 'closing my eyes' only became relationally distinct and no longer seemed to exist as separate individual elements.

Continuing to take ordinary, mundane matter and practices found within early childhood landscapes the chapter moves to Ladybird Room, in London, at Christmas time. Ladybird 
Room is 'the toddler room' but it is also a space occupied by non-human and other-thanhuman agents. It is a familiar environment, looking remarkably like many other 'toddler rooms' in nurseries up and down the UK. But in many senses Ladybird Room in its mundane, familiarity is extraordinary, it holds the potential to generate fresh understandings about 'multi-culturalism' in early childhood when attention is paid to entanglements and the material-semiotic-discursive processes through which diversity manifests in unexpected ways.

Like 2-Curious, this study demanded a sense of researcher as non-expert be embraced and to take up Haraway's (2016) invitation to 'Stay with the Trouble' so that habitual practices of gathering, recording, coding and interpreting might be dismantled and so generate other ways to encounter and sense cultural diversity. Working to rethink habitual practices in research urges a focus on the small stuff, the intra-actions between researcher, spaces, place, matter, sensations. Allowing ourselves to get caught up in movements and processes, sensing the multiple intensities that coalesce in events - but all the while retaining the political imperatives underpinning research in and for early childhood.

Re-thinking, re-feeling, re-folding ideas about diversity in early childhood involves attention to micro-events, ordinary routines and mundane situations, sensing intensities and what MacLure (2015) terms 'glow' moments. To be open to what else might be there; to reconfigure and stretch ideas about diversity and difference and how it is produced through everyday, seemingly unremarkable events and intra-active processes. Without clear intent, the research sought to register the messy entanglements of matter, affect and bodily expression during 'events': celebrations and festivals (e.g. Christmas) to reimagine how cultural diversity and difference plays out, is embodied and expressed in early childhood contexts.

Guiding the study was the goal to generate multiple and experimental ways of (not) knowing and so avoid getting stuck in familiar ways of thinking and doing. Reconfiguring diversity in early childhood contexts involved multiple processes of charting the terrain, experimenting and resisting the comforts of recognition, reflection and identification. 


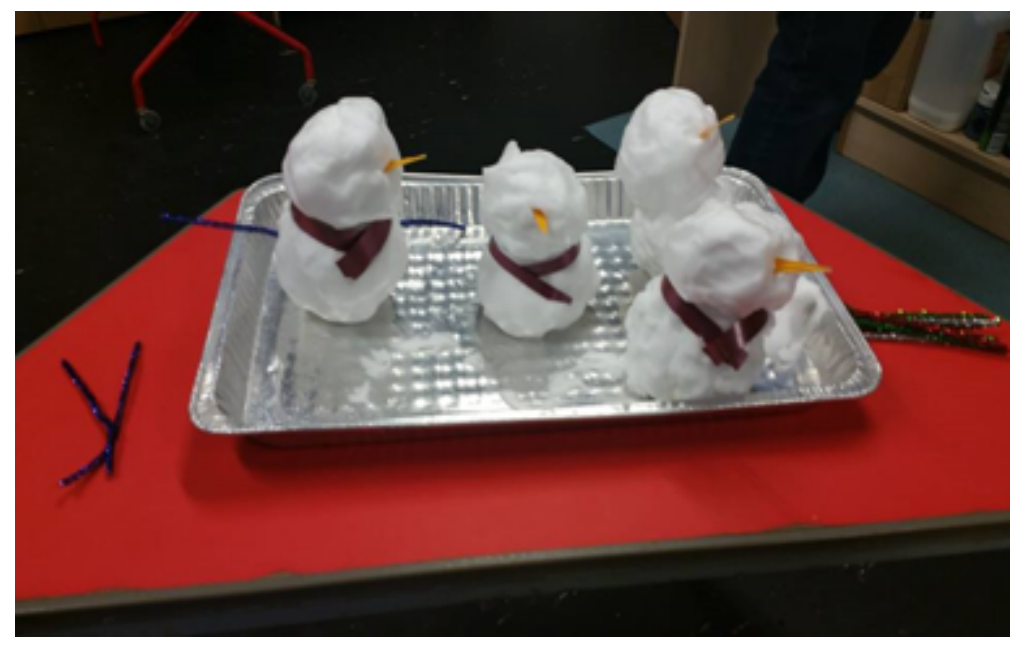

I am immediately hailed by a congelation of shaving foam snowmen ${ }^{1}$ [sic]; carefully crafted, uniform in size, some adorned with scarves and noses, left for future play/work- for now, neglected snowmen sit expectantly. A line of empty shaving foam cans by the sink suggest snowmen are a regular, habitual feature of the pedagogical practices within Ladybird Room.

What does shaving foam make possible?

Near-empty cans of shaving foam invite a trio of boys. Squirting, spluttering, hissing, ceasing to offer smooth balls of foam, noisy spray, laughter, mess. Two girls become entangled, shavingfoamsnow sprayed over the carefully prepared and expectant snowmen: "It's a blizzard, look it's snowing, we've made a blizzard". Animated laughter, slowly, painfully slowly, the can empties; entranced by/through chaos, mess, noise. In mock horror: 'What's happened to my snowmen!?!'

\footnotetext{
${ }^{1}$ The nursery staff recognise the environmental factors associated with using shaving foam. Efforts are made to use products that have minimal environmental damage, which includes ensuring that the cans are recyclable. The staff are also debating with the children the ethics around using food such as flour, lentils and pasta when undertaking certain craft activities.
} 


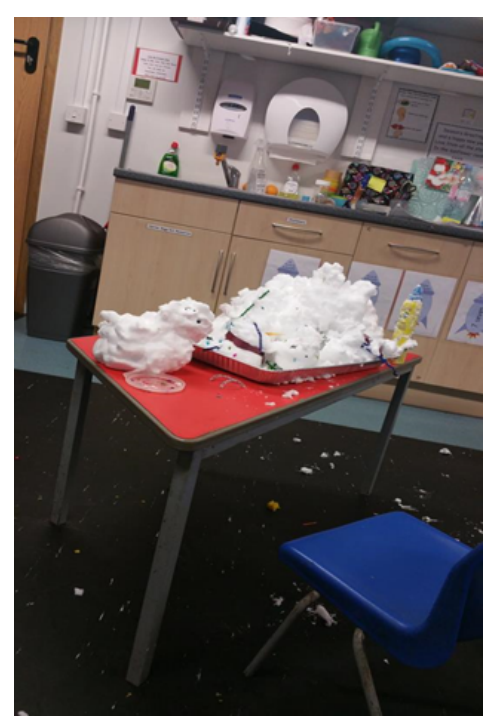

A vocal undertone suggestive of displeasure, frustration, deflation. Handfuls of 'snow' squeezed through fingers, passed from hand to hand; delving back into the blizzard mound for fresh handfuls, laughter, joy, concentration, pleasure. A sheet of boggly eyes - no use to the buried snowmen. Children becoming snowmen -boggly eyes stuck to cheeks, cut-out carrot noses stuck to faces with blobs of shaving foam - hilarity -jumping - up-down-updown-flapping-circling - jumping eyes that boggle. Soon all the children, and the researcher are jumping high to make the extra eyes boggle. Raucous laughter, frenetic energy - still the snowmen remain buried and neglected....

Meanwhile a lone girl with a slight frame sits quietly at the next table, deeply engrossed, crafting Christmassy shapes from Play-doh (green with red glitter mixed in). Methodically rolling and cutting the dough with Christmas shape cutters. Completely divorced from the shaving-foam-blizzard-boggly-eyed-bouncing assemblage at the next table. Doesn't speak; wondering: is English not her first language? Fair black skin, delicate features, tightly braided hair, cornrows. Children move to the play-doh table: invasion ...discomfort, searching looks for an adult, communicating without words or signs, both move gently to the abandoned shaving foam table.

What does the shaving foam snow make possible?

Calmness, quiet, handfuls of foam simultaneously crafted in to smooth balls. Reassured, contentment at physical proximity of the educator and absence of the rowdy crowd. Deep immersion with the foam - careful and gentle, moulding a smooth ball, extra scoops to increase the size of the ball, smoothed, swelling, all-consuming. Weightlessness of the foam 
produces mime-like motions. How unlike snow shaving foam is - not cold, not wet, no crunch, no solidity at all. Wondering: has this girl ever handled 'real' snow?....

What does the shaving foam snow make possible?

With time and care a fresh set of snowmen are crafted by this lone girl and the educatorworking in parallel, without interaction or words spoken they have an ease about their relationality and familiarity with the task. The educator intermittently assists (party hats down from a high shelf, scissors, something else and something else) - the educator leaves the girl by herself; seems unfazed... children approach the table - she stops - she freezes remains mute, expressionless but frozen. They move away, she resumes shaving-foam-snow. The crafting of snow balls, texture of the foam...calming, all-consuming - as with case with the play doh previously. Wondering: how matter matters.

These observations might generate familiar thoughts. Deconstructing and critiquing takes us to familiar places both theoretically and politically. Interpreting that which appears to be represented in this scene (re)tells stories about race and ethnicity, gender, SEN, ESOL, pedagogical practices, that are all too familiar. Putting to work feminist new materialism makes materiality and entanglements the starting place and enables us to re-think thought. We are freed from the anthropocentric concern to know and fix the child-subject. We are offered other, less certain possibilities. The shaving foam makes possible other ways to rethink thought about early childhood; cultural diversity manifests multiply through the events, the entanglements, the assemblages as fleeting, fluid, shifting, co-constituted and processual rather than fixed and residing within the subject. Taking the cardboard box and the shaving foam snowmen as multiple and interwoven material-semiotic-discursive entanglements provides us with something to think with.

Working with post-humanist epistemologies opens up possibilities to chart curriculum frameworks and research methods against what unfolds in the routine, everyday events in nursery environments - possibilities emerge between the porosity of discursive discourses and materialised practice. Dominant discourses readily perceptible include child development, multi-culturalism, scaffolding pedagogies, free flow, social interaction, sensory play and so on. But Haraway's practice of becoming-worldly-with begs that we consider the inter- and intra-relationality between human, non-human, more-than-humans and everyday life and how it is situated politically, historically and geographically.

Bennett (2010) shifts focus from the human experience of things to things themselves. She explores how political analyses might change if we acknowledge that agency always emerges 
in the ad hoc configurations of human and nonhuman forces. Recognising that agency is distributed in this way, and that it is not solely the province of humans, might spur the cultivation of a more responsible, ecologically sound politics: a politics less devoted to blaming and condemning individuals than to discerning the web of forces affecting situations and events. Taking the cardboard box; taking the shaving foam as something to think with, as a means to figure, putting to work Bennett's ideas of 'thing power' and vital materialism in early childhood contexts we might ask: What does becoming shaving-foam-snow make possible? How does it function and connect with other things? What intensities does it stimulate or allow or refuse? What traces does it leave?

This questioning can prompt investigations into the assemblages of relational entanglements within the event itself: boggly eyes, too small furniture, cornrows, music, clocking practices, food, mirrors, hissing, silence, jumping, flapping, laughter, dismay/frustration, inclusion/exclusion - but also what informs the agents within the assemblages and where they might take us. These complex assemblages of relational entanglements offer another way to consider the politics of seemingly inconsequential events and everyday occurrences within early childhood contexts. In order that educators and researchers might persistently grapple-with so as to produce alternative and more expansive understandings that might offer the space to collectively identify and re-imagine matters of concern and shared problems in early childhood contexts. Educators are offered the chance to become entangled with the materiality of their practice in ways that enable a critical engagement with the structures of policy, curriculum with which they are expected to work and which they in turn shape.

The not-knowingness of research framed by feminist new materialism means that we cannot know in advance what will emerge but it invites an exploration, to try things out that might not work. The goal of research in this mode of inquiry is more open-ended and shaped by uncertainty that invites us to be curious, to wonder, to wander, to question, to falter. To recognise that we do not have the solution because there is no one solution. But there are ways in which we can open ourselves to the not-yet and not-known rather than falling into old orthodoxies about what we think we know about childhood, diversity and education - that merely reflect back and reinscribe.

We need to stay with the trouble of children's matters of concern as experienced and witnessed in everyday encounters and routine events. Expanding our conceptions of the child, beyond humanist concerns with the subject, to children as entangled and of the world; creates ways to reshape ideas about pedagogical and research practices, advocacy and activism. The 
becoming-shaving-foam-snow provides a 'reference point for new questions, new practices and new values' (Stengers, 2010, p.5). It creates spaces for entanglement to offer generative possibilities to pursue ambitions for experimental and creative, politically framed practices that offer generative potential.

\section{Concluding re-thought thoughts}

Previously we made the point that when (re)search(ing) the desire was to allow for the play of intensive forces because it was within and amongst these that there were possibilities for challenging habitual ways of thinking and habitual ways of claiming knowledge. We would like to suggest that both of the examples assemble human and non-human bodies, which in turn constitute both "an event and a sensation" (Stewart, 2010, p. 4). We want to also suggest that the two examples are imbued and carry with them forces and movements that in our view work against the "convulsive tics", that is, the "machinic repetitions" that can characterise research and which "serve to curtail the subject's capacity to affect and be affected, and which limit the field of possible becomings" (Ravaisson, 2008, p. 51).

Finally, the examples avoid making definitive claims and in so doing they both work at diminishing the role and position of us as researchers. So rather then being positioned as 'agents on hot pursuit of something definitive" we are caught trying "to become attuned to what a particular scene might offer" (Stewart, 2010, p5).

\section{References}

Ahmed, S. (2004). The Cultural Politics of Emotion. Edinburgh: Edinburgh University Press. Barad, K. (2003). 'Posthumanist Performativity: Toward an Understanding of How Matter Comes to Matter'. Signs: Journal of Women in Culture and Society, 28(3) p. $801-831$. Barad, K. (2007). Meeting the Universe Halfway: Quantum Physics and the entanglement of matter and meaning. Duke University Press: London.

Bennett, J. (2010). Vibrant Matter: A Political Ecology of Things. USA: Duke University Press.

Biesta, G. (2007). Why “What Works" Won't Work: Evidence-Based Practice and the Democratic Deficit in Educational Research. Educational Theory, Volume 57 (1), Issue 1: 122

Bissell, D. (2012). 'Agitating the Powers of Habit: Towards a Volatile Politics of Thought'. Theory and Event, Volume 15 (1). Accessed 09.04.17 at https://muse.jhu.edu/article/469326. Blackman, L. (2012). Immaterial Bodies Affect, Embodiment, Mediation. London: Sage. Braidotti, R. (2006). Transpositons: On Nomadic Ethics. Cambridge: Polity Press. Braidotti, R. (2013). The Posthuman. USA: Polity Press.

Brennan, T. (2004). The Transmission of Affect. Ithaca: Cornell University Press. Cannella, G.S. and Soto, L.D. (2010). Childhoods: A Handbook (Rethinking Childhood). US: Peter Lang Publishing Inc. 
Cannella, G.S., Pérez, M.S., \& Lee, I.F. (Eds). (2015). Critical examinations of quality in childhood education and care: Regulation, disqualification, and erasure. New York, NY: Peter Lang. https://www.peterlang.com/view/product/31229?format=EPUB Clough, P.T. (2007). 'Introduction', in P.T. Clough (ed). The Affective Turn. Durham: Dule Universoty Press.

Cull, L. (2009). Deleuze and Performance. Edinburgh: Edinburgh Press.

Dahlberg, G., Moss, P. \& Pence, A. (1999/2013). Beyond Quality in Early Childhood Education and Care: Languages of Evaluation. London: Routledge.

Deleuze, G. (1994). Difference and Repetition. Trans. Paul Patton. New York: Columbia University Press.

Deleuze, G. (2013). Francis Bacon. London: Bloomsbury.

Deleuze, G. and Guattari, F. (1994). What is Philosophy? London: Verso Books.

Deleuze, G. and Guattari, F. (1987). A Thousand Plateaus: Capitalism and Schizophrenia.

Trans. Brian Massumi, London: Continuum.

Department for Education (2011) Supporting Families in the Foundation Years. London: Crown Copyright.

Department for Education (2015). 2-year-old early education entitlement: local authority guide. London: Crown Copyright.

Dolphijn, R. \& van der Tuin, I. (2012). New Materialism: Interviews \& Cartographies. US: Open University Press.

Guillaume, L. and Hughes, J. (Eds)(2011). Deleuze and the Body. Edinburgh: Edinburgh University Press.

Haraway, D.J. (2016). Staying with the Trouble: making kin in the Chthulucene. Duke University Press: London.

Hickey-Moody, A. (2016). Manifesto: The Rhizomatics of Practice as Research. In Anna Hickey-Moody, Tara Page (Eds.), Arts, Pedagogy and Cultural Resistance: New

Materialisms, (pp. 169-192). London: Rowman \& Littlefield Publishers Inc.

Hroch, P. (2015). 'Deleuze, Guattari, and Environmental Pedagogy and Politics: Ritournelles for a Planet-yet-to-come'. In M. Carlin and J. Wallin, (Eds)(2015). Deleuze and Guattari, Politics and Education: For a People-Yet-to-Come. London: Bloomsbury Academic.

Holmes, R. \& Jones, L. (2016). 'Flickering, spilling and diffusing body/knowledge in the posthuman early years'. In C. A. Taylor and C. Hughes (Eds)(2016). Posthuman Research Practices in Education. Hampshire: Palgrave, pp 108 - 127.

Kirby, V. 1997. Telling Flesh: The Substance of the Corporeal. New York and London: Routledge.

Knudsen, B.T. and Stage, C. (Eds)(2015). Affective Methodologies: Developing Cultural Research Strategies for the Study of Affect. Hampshire: MPalgrave Macmillan.

Lapworth, A. (2015). 'Habit, art, and the plasticity of the subject: the ontogenetic shock of the bioart encounter'. Cultural Geographies. Vol. 22(1), pp 85-102.

Latour, B. (2004). 'Why Has Critique Run out of Steam? From Matters of Fact to Matters of Concern'. Critical Inquiry. 30 (Winter 2004): 225 - 248.

Law, J. (2004). After Method: Mess in Social Science Research. London: Routledge.

MacLure, M. (2013). 'The Wonder of Data'. Cultural Studies $\leftrightarrow$ Critical Methodologies, 13(4): $228-232$.

MacLure, M. (2015). 'The New Materialisms': Thorn in the Flesh of Critical Qualitative Inquiry? In G.S. Cannella, M.S. Pérez and P.A. Pasque (Eds)(2016). Critical Qualitative Inquiry: Foundations and Futures. London: Routledge, pp 93 - 112.

Massumi, B. (1998). 'Event Horizon'. In J. Brouwer (Ed)(1998). The Art of the Accident. Rotterdam : Dutch Architecture Institute/V2, pp.154-168.

Massumi, B. (2002). A Shock to Thought: Expression after Deleuze and Guattari. London: Routledge.

Mitchell, R. (2010). Bioart and the Vitality of Media. Seattle: Washington University Press. 
Moss (2014)

Moss, P. (2016). 'Towards a holistic approach to early childhood education'. In C.Dalli and A.Meade (Eds)(2016). Research, Policy and Advocacy in the Early Years: Writings inspired by the achievements of Anne Smith, New Zealand: NZCER, pp.109-120.

Olsson, L.M. (2009). Movement and Experimentation in Young Children's Learning: Deleuze and Guattari in Early Childhood Education. London: Routledge.

Olsson, L.M., Dahlberg, G. and Theorell, E. (2015). 'Discplacing identity - placing aesthetics: early childhood literacy in a globalized world'. Discourse: Studies in the Cultural Politics of Education. Volume 37(5), pp 717 - 738.

Rancière, J. (2001). Ten Theses on Politics. Theory \& Event, 5 (3). Accessed on $13^{\text {th }}$ November at

http://www.after1968.org/app/webroot/uploads/RanciereTHESESONPOLITICS.pdf. Ravaisson, F. (2008). Of Habit, trans. C. Carlisle and M. Sinclair. London: Continuum. Stewart, K. (2007). Ordinary Affects. London: Duke University press.

Stengers, I. (2010). Cosmopoltics I. Minneapolis: University of Minnesota Press.

Svirsky, M. (2015). 'BDS as a mediator'. Literary and Cultural Studies, 41(2): 45 - 74.

Thrift, N. (2008). Non-Representational Theory: Space, Politics, Affect. London: Routledge.

Wallin, J. (2013). 'Morphologies for a Pedagogical Life'. In I. Semetsky and D. Masny (2013). Deleuze and Education. Edinburgh: Edinburgh University Press, pp 196 - 214. James Williams (2013) Gilles Deleuze's Difference and Repetition: A Critical Introduction and Guide, Edinburgh: Edinburgh University Press.

Wood, B. (2014). 'Making Sense of No Body. Journal of Creative Technologies, Issue 1. Accessed $15^{\text {th }}$ November 2017, at https://ctechjournal.aut.ac.nz/paper/making-sense-body/. 